\title{
Which club does your Alliance belong to? An empirical classification of strategic alliances in post-transition Hungary"
}

\author{
Zoltán Buzády ${ }^{* *}$
}

The article focuses on possible typologies of strategic alliance. The first section gives a brief overview of the major groupings of alliances followed by the detailed description of strategic alliance history in Hungary. Former alliance theories were not able to describe sufficiently the characteristics of Hungarian strategic alliances because those theories origin in the business environment of western economies. The author presents a new classification of strategic alliances of post-transitional Hungary based on empirical researches. Three new groups arise, namely „cautious partner”, „members only club” and ,waiting for the white knight”.

Der folgende Beitrag hat die Typologisierung von strategischen Allianzen zum Thema. Im ersten Teil werden die wichtigsten Modelle zur Einordnung von Allianzen vorgestellt, anschließend wird das Umfeld sowie die Entwicklung von Unternehmenskooperationen in Ungarn erörtert. Da jedoch alle bisherigen Klassifizierungsmodelle in erster Linie dem westlichen Wirtschaftsumfeld entspringen, können diese die Besonderheiten ungarischer Unternehmenspartnerschaften nicht ausreichend beschreiben. Der Autor präsentiert eine neue, auf umfassenden empirischen Studien fundierte Einteilung der strategischen Allianzen im Post-transitionsland Ungarn, so entstehen die drei neuen Gruppen: "Sicher ist Sicher", „Der Members-Only Klub“ sowie „Die Traumtänzer".

Key words: Strategic alliances / strategic management / organisational change / post-transition economies / empirical research,

\footnotetext{
* Manuscript received: 23.08.03, accepted: 18.04 .05 (1 revision)

** Zoltán Buzády, Assistant Professor at the Budapest School of Management of BUESPA. Main research areas: Strategic alliances, corporate strategy, international business and organisational behaviour. Corresponding address: Buzady@bsm.hu
} 


\section{Introduction ${ }^{1}$}

Over the last one or two decades research into the phenomenon or seeming contradiction of cooperating competitors, that is strategic alliances, has highly proliferated. This article is to test the validity of the western models describing strategic alliances within the Central European region (Hungary) during the transition years of the late 1990's. On a more fundamental note, the basic issue raised in this paper is the transferability and appropriateness of western management models to the Central European region.

The goal of this paper is to empirically research the validity of western typologies of strategic alliances. Alternatively, the goal is to explore whether observed alliances can be better regrouped along other, newly defined dimensions.

The methodology chosen for the present research was to collect a representative, large-scale database of companies engaged in strategic cooperations, whilst the appropriate unit of observation was chosen to be the given strategic alliance. Factor analysis was used for better describing the numerous characteristics of the observed alliances along fewer, new dimensions. In the second step cluster analysis was used to create groups of strategic alliances based on their relative closeness to each other. Thus we obtained an operational number of groups of alliances. In the third step both findings were combined to create a new typology and so to interpret the new clusters of strategic alliances with the help of the newly found explanatory dimensions.

This paper is structured in following sections. First, the most common western typologies and models describing strategic alliances are introduced. Second, alliances are explored in the Hungarian context, whilst great emphasis is placed on demonstrating their roots in the national state-system (such as monolithic corporations, forced and not market-based economic exchange mechanism). Hungarian and Central European economic and management context of the 1990 's in general can be characterised by the influx of western business strategies and management approaches. This flow is the second stream which strongly influenced the development of strategic alliances in Hungary. This fact raises the fundamental question of this paper: did all that influx affect the types of alliances observed in Hungary? In how far did they differ from those described in western academic literature? In the subsequent sections we describe the rigorous statistical methodologies applied in the empirical research and we present the results. Finally, findings are interpreted, which results in a new typology of strategic alliances in Hungary of the late 1990's.

1 This article is the revised version of the paper presented at the VIth Chemnitz East Forum and which received the JEEMS "Best Paper" award. The author wishes to thank the organisers and reviewers for their helpful comments. 


\section{Typologies of strategic alliances - the western ,classics”}

With the continuous spread of inter-company cooperations over the last one or two decades academics and business consultants have developed a number of different models aimed at classifying the various forms of cooperations. The dimension along which alliances are being classified into separate groups can be related to the characteristics of the alliance, to the nature of the partners involved, to the dimensions of the parent company or even to the industry structure. The many typologies include both normative and descriptive approaches to describing alliances. They also differ in their research methodology. The method chosen by most researchers (in this field) is the questionnaire study. It has been used by Faulkner (1995), who observed about 70 alliances, Dussauge and Garrette sampled 128 reported alliance cases (1995) and Garcia-Canal's study was based on 663 alliances (1996). Hergert and Morris even worked on 839 collaborative agreements (1987). The other major research stream is to base the alliance models on a collection of case studies. This activity compiles sets of separate monographs and reports of highest clinical precision. The results and observations on a series of strategic alliances, gained through a limited number of deep interviews, are then extrapolated to the wider context of company strategy (Dussauge/Garrette 1993; Bidault/Cummings 1994; Dussauge/Garrette 1995; Child/Markóczy 1993).

The next section will be presenting different approaches, which will be helpful in clarifying and structuring the various possible types of alliances.

\subsection{Types of alliances - a historic overview}

The most basic and most frequent line of distinction drawn between alliances is linked to ownership in companies. As already described in detail in the section on transaction theory, equity is used to differentiate between so-called equity alliances. They are defined to be either organised as an equity joint venture, which involves the creation of a new and independent jointly owned entity, or alternatively equity alliances can occur when one of the partners takes a minority equity position as the other partners (Pisano 1989). Thus Hennart distinguishes between equity joint ventures which create a new legal entity from various sponsors' assets on the on hand and non-equity joint ventures on the other. For the former questions related to ownership and profits become relevant while the latter encompasses all contractual forms, licences, distribution arrangements and contracts to manage.

The reasons for choosing equity relationship for a cooperation is that a joint venture can be a useful device to bypass inefficient markets for inputs, whereas the market failure i.e. high transaction costs, can depend on many factors.

Another important early attempt to classify alliances in terms of their competitive impact has been made by Michael Porter. He uses the term 
„coalitions" for what most scholars refer to as strategic alliances. His terminology includes long-term agreements among firms that reach beyond normal market transactions but fail to reach outright mergers. Coalitions include licenses, supply agreements and joint ventures. They are ways to broaden the scope without broadening the firm by contracting with an independent firm to perform value activities or cooperatingwith an independent firm to share activities. „Coalition partners remain independent firms. The relative bargaining power of each partner is thus central to how the gains are shared, and determines impact of the coalition on a firm's competitive advantage" (Porter 1985).

Coalitions can potentially be formed to perform any activity or group of activities in the value chain. The following basic types of alliances, focusing on different parts of the valued chain activities, tend to emerge, namely technologydevelopment coalitions, operations and logistics activity coalitions for scale and learning economies, and marketing, sales and service coalitions to cope with national differences. In fact, alliances may cover more than one valued activity, so they are multiple-activity coalitions (Ghemavat et al. 1986).

As it becomes obvious from above earlier writings focused mostly on some general form of cooperation. The term alliance itself has only emerged subsequently. The above quoted authors focused their articles and books on other aspects than cooperation. They merely raised those questions, which now form the core of strategic alliance research. All earlier pieces of literature on cooperations can be considered not exhausting because they analysed cooperation only along one single dimension.

\subsection{Taxonomy of strategic alliances}

Lorange and Roos propose a two-step conceptual scheme for the classification of strategic alliance (see figure 1). Following the first step of identifying possible motivations for alliance formation, generic strategic alliance types are established „based on the resource input/output perspective” (Lorange/Roos 1992). Regardless of underlying motives, a fundamental concern of each prospective strategic alliance parent is the question of how much of its resources are put into and retrieve from a strategic alliance. At the one extreme, of the input side, a parent may wish to put in only organisational resources such as people, technologies, funds and staff support. At the other extreme it may be willing to put in sufficient strategic resources for the alliance to adapt to an array of potential changes in the environment. A self-adapting alliance would require more resources. The value created in the alliance can also be considered on a continuous dimension. On the one end, Lorange and Roos identify the parents' taking back all the output resources of the alliance (profit taking, staff call-back et cetera). At the other extreme, all of the output created is retained and built up in the alliance itself. 
Figure 1. Archetypes of strategic alliances (Lorange/Roos 1992)

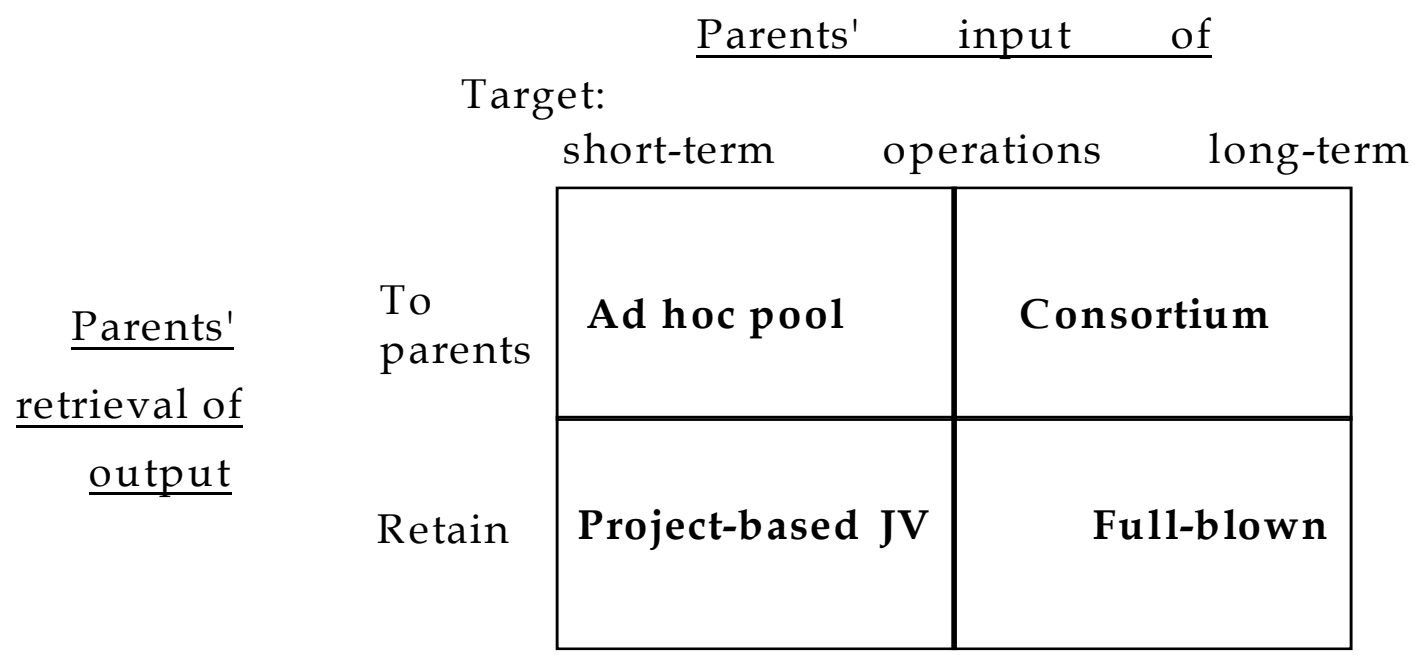

A number of different aspects can be identified as important characteristics of alliances. Consequently, certain inadequacies and ambiguities arise when classifications of alliances are only researched along two dimensions. Faulkner therefore suggests to cluster alliances along dichotomous dimensions (see figure 2) (Faulkner 1995): The first dimensions distinguishe between collaborative arrangements established to meet a clearly defined set of circumstances in a particular way on the one hand and so-called 'complex alliances' on the other. The latter may involve certain parts of or even the entire organisation of each partner. The companies recognise that, in combination, they form a potentially much more powerful competitive enterprise than they do individually, but they wish to retain their separate identities. The second dimension draws a line between separate legal-entity joint ventures and more flexible, increasingly project-based collaborations. The third dimension groups alliances according to the number of partner companies: bilateral or consortium. 
Figure 2. The strategic alliance options (Faulkner 1995)

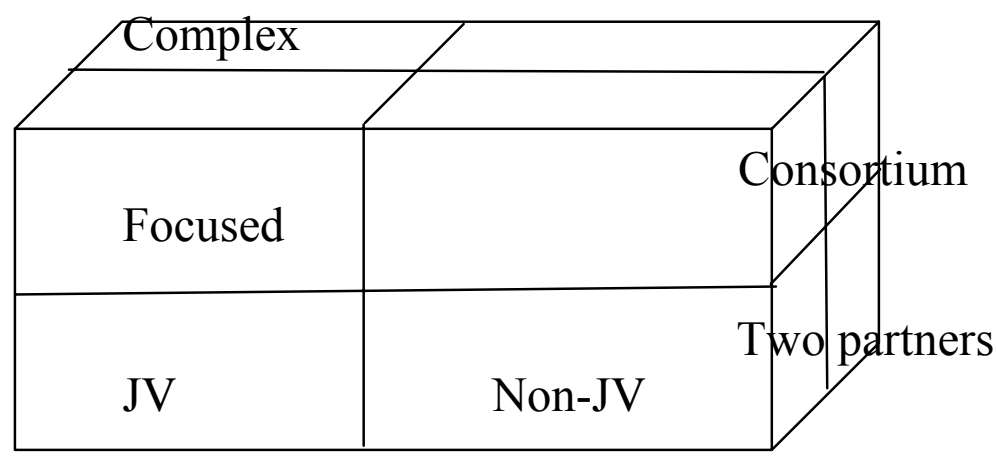

Figure 3. Inter-firm links (Yoshino/Rangan 1995)

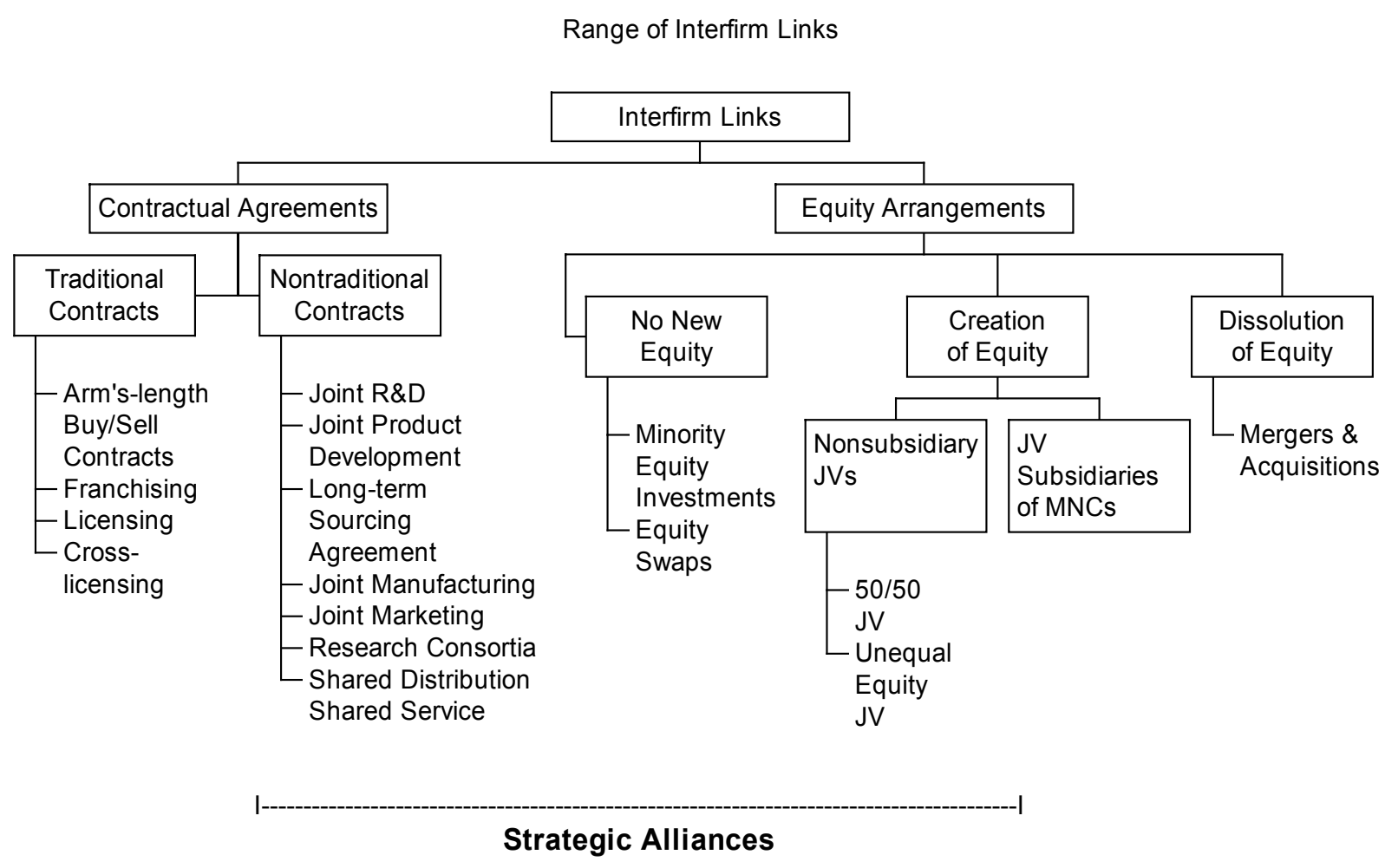

Similarly to this is the categorisation by Bühner (1993), who uses several criteria to distinguish between alliances, namely by the direction of the alliance (such as horizontal or vertical), by the scope of the alliance (that is different functional areas) and by the type of partners involved (such as medium-sized or large companies). Yoshino and Rangan (1995) (see figure 3) have a more limited view on inter-firm arrangements. They exclude overseas subsidiaries of multinational corporations, even if they are joint ventures, from strategic 
alliances. These collaborations are undertaken for the purpose of entering new geographic markets solely. They are often tactical or reactive responses by MNE to host nation government pressures. The 'jointness' of a venture is rather a compromise than a goal, and control tends to rest with the MNE. Similarly, licensing and franchising agreements are not strategic alliances because they do not call for a continuous transfer between the partners. The following figure however illustrates the authors' range of possible interfirm links and the subset encompassed by their definition of a strategic alliance.

Figure 4. Directions of strategic alliances and potential partners (Tari/Buzády 1998)

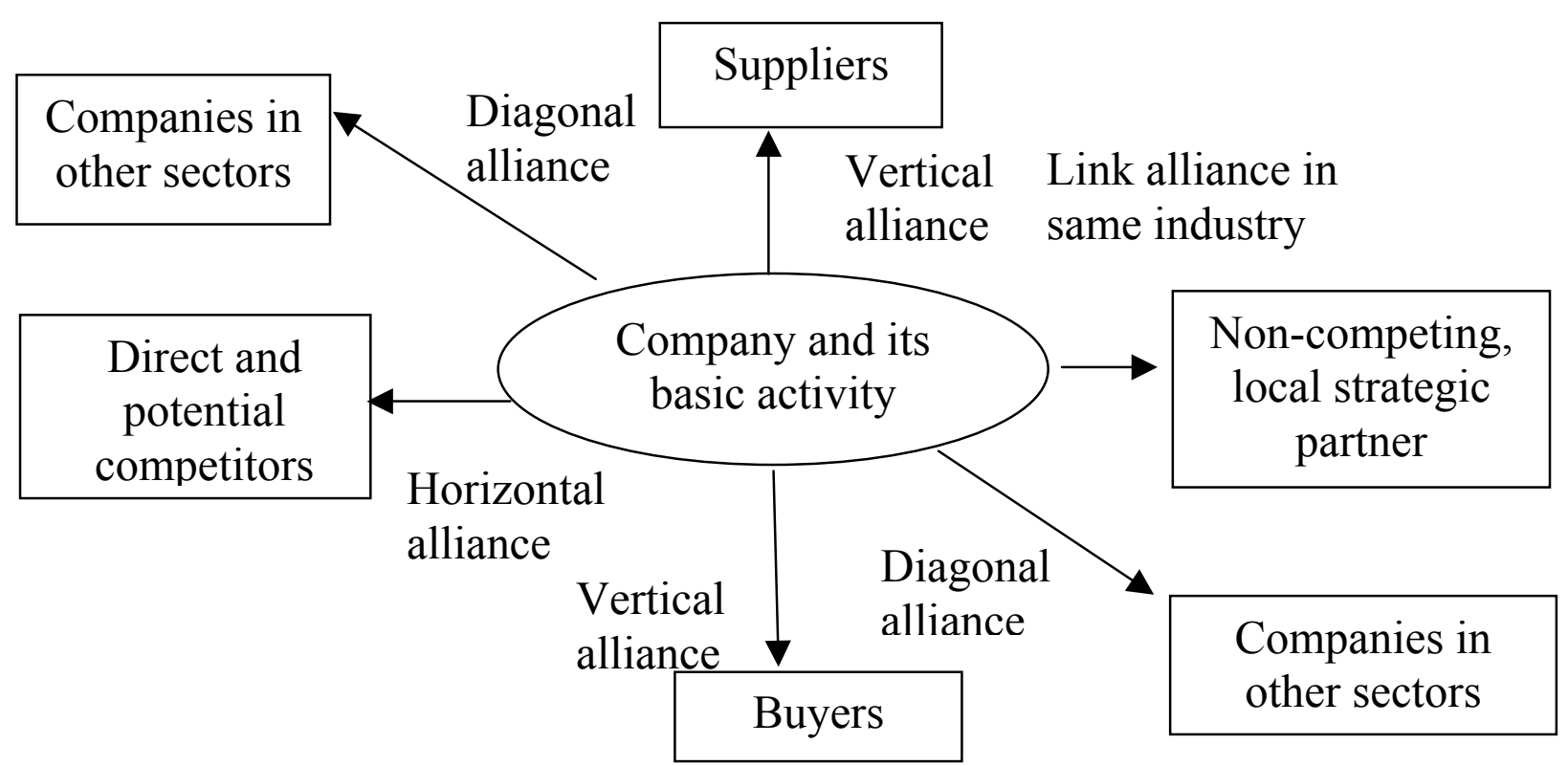

But alliances can also be divided into several other clearly distinct categories. At a first level, it seems important to distinguish partnerships forged between companies from different industries, which are therefore notin direct competition with one another, and from alliances between rival firms, which raise specific problems, both from an anti-trust point of view as well as in terms of managing the relationship between the allied competitors. At a second level, within partnerships between non-competing firms, a useful distinction can be made between international expansion joint ventures, vertical partnerships and cross-industry agreements. As for alliances between rival firms, Dussauge and Garrette (see figure 4) have suggested an original analytical model derived from extensive research conducted on a large sample of such alliances. Their model shows that strategic alliances uniting rival firms can be divided into three main categories: shared-supply alliances, quasi-concentration alliances and complementarity. 


\subsection{Partnerships between non-rival firms}

These alliances are formed by companies belonging to different industries (see figure 5). The companies concerned aim to expand into areas new to them, areas in which the partner can make valuable contributions. These alliances are an alternative to more traditional forms of expansion such as Greenfield investments or acquisitions. Growth options are international expansion, vertical integration or diversification.

\subsection{Partnerships between competing firms}

The very existence of alliances between rival firms is paradoxical. Competitors are expected to compete with one another rather than to join forces. The nature of the relationship between allies has been interpreted in two totally opposing ways:

Figure 5. Expansion options and types of non-rival partnerships based on (Dussauge/Garrette 1995; Tari/Buzády 1998)

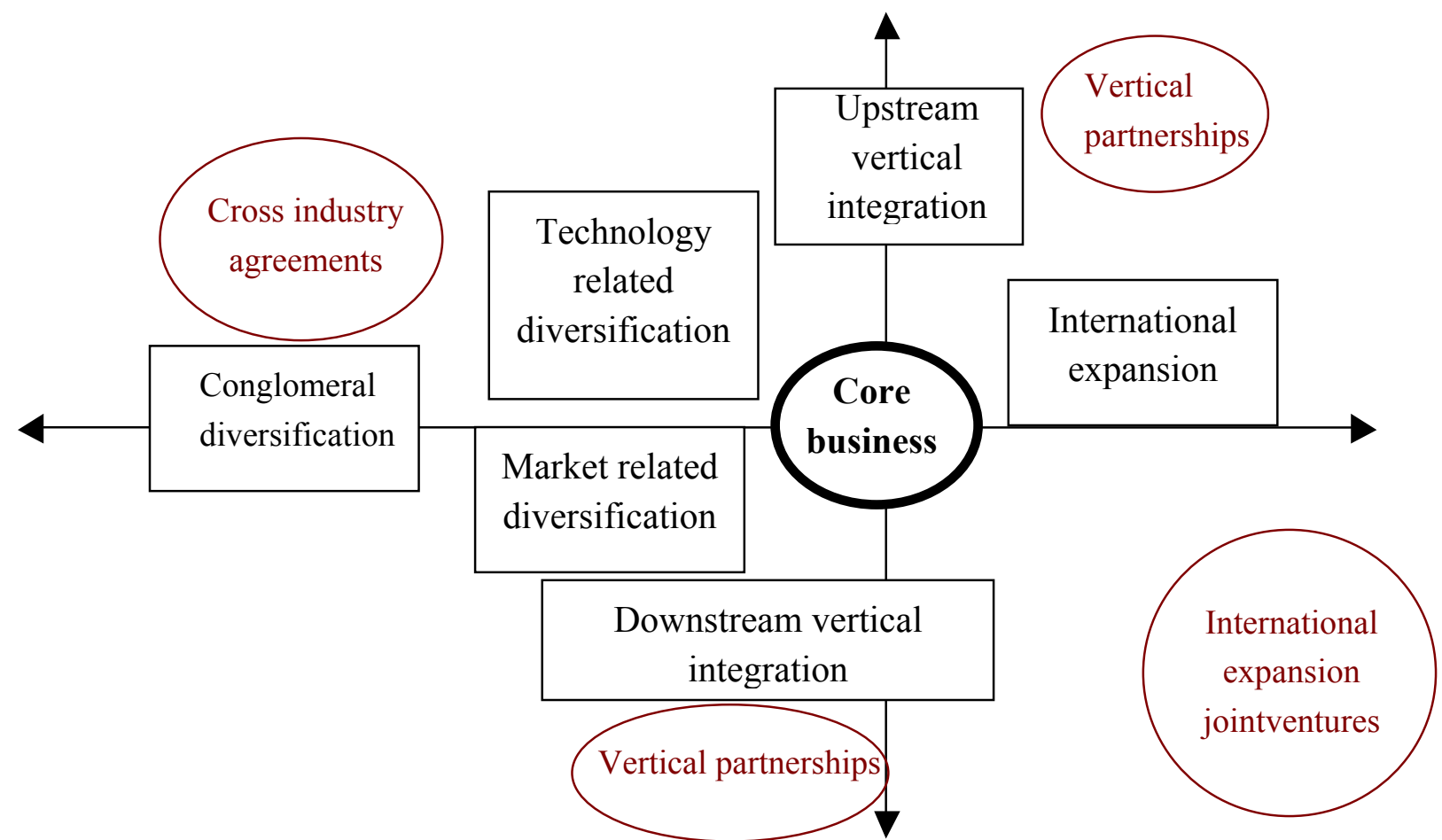

- For some commentators, all alliances between competitors should be considered as collusive behaviour. They are assumed to eliminate competition between the allies and to collectively strengthen the partners' position in relation to their environment, i.e. other competitors, suppliers, customers etc. (Arndt 1979).

- For others, alliances between competitors do not eliminate inter-partner rivalry, they only modify the forms that this rivalry takes. According to 
this perspective, such alliances are a zero-sum game in which one partner is bound to lose what the other gains (Doz et al. 1989). Alliances are thus predicted to generally result in unbalanced outcomes.

An equal mistake will be to assert either to be paramount truth.

\section{Strategic alliances in the Hungarian context}

\subsection{Historic overview}

Nationalisation and merging enterprises were an important tool for the artificial centralisation of the Hungarian economy. After the forced merging of numberless small- and medium-sized enterprises during the 1950's the newly formed industrial enterprises with a single, main location predominated. The newly created large enterprises were hoped to increase national economic output and efficiency levels. „Many subscribed to the fundamental belief that the larger enterprise produces superior efficiency in all aspects. After this period of forced merging virtually no Hungarian management research has been conducted about the new forms of division of labour between companies and cooperation at the top level of enterprise management" (Tari 1988).

The centralisation process led not only to production, organisational and strategic inertia but also to shortages and to the inefficiencies caused by the lacking of a market co-ordination mechanism. In order to counterbalance these problems, the economic policy action taken was to enhance the vertical integration of larger enterprises. First, the small supplier companies were merged into to the structures of the larger enterprises, later the whole production processes were planned in such a manner that the total vertical production chain was done within the large enterprise.

Large Hungarian enterprises thus tried to solve as many problems within their own organisation as possible;they aimed at becoming as independent as possible. During the 1980's a certain amelioration of the economic climate was observable and the supplier enterprises started to grow: the large state enterprises gained the autonomy to differentiate between the various suppliers and to build relations with potential entrepreneurs and subcontractors. In this way they managed to „create semi-autonomous partnerships within the large state enterprise" (Bruszt/Stark 1998). Despite of these partnerships, this development cannot be considered as a fundamental structural change because the possible advantages (such as economies of scale and scope or the building of core competencies) arising from specialisation and cooperation did not materialise, mostly due to the remaining monopoly position of the large enterprises. 
Functioning inter-organisational networks and relationships based on the principles of the market such as inter-organisational information networks, joint projects or strategic alliances only emerged during the 1990's.

One of the basic legal frameworks for the fundamental political, social and economic changes of the 1990's was postulated by the Business Companies Act in 1988. The main goal of placing economic actors, i.e. companies, into a more modern legal context was to accelerate the economic processes and to enhance their efficiency. The result was expected to show itself in the development of market cooperations, the realisation of capital investments and in the increase of foreign direct investments.

The political changes and the new legal regulations governing the status of companies, however, induced the gradual decline of activity co-ordination by central governmental authorities and gave place to market-based competition and enabled the establishment of new inter-organisational relationships. Some companies have worked as subcontractors for western companies as early as the 1970's and their products appeared on western markets. This situation was an oppportune moment for managers to participate in the learning processes induced by organisational changes, and to the acquisition of individual and organisational skills needed for successful continuous change" (Balaton et al. 1996). However, the two companies could then also obtain additional (i.e. western) financial means, which helped to survive the first years of radical transformations in Hungary. The existing tight cooperation relationship with strategic investors enabled the company to invest well below the Hungarian bank interest rates.

Figure 6. Factors of company transformation (Buzády 2000)

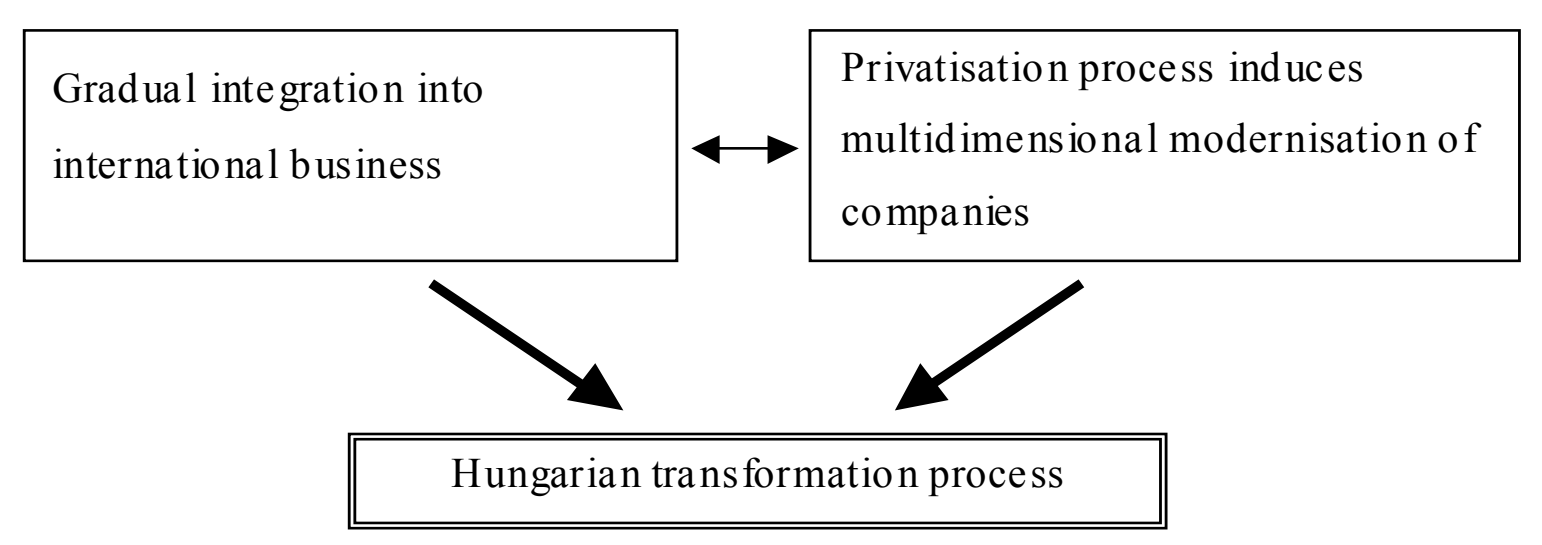

\subsection{Strategic Alliances in Hungary}

What kind of factors can be find to have influenced the reorganisation of organisational structures and inter-organisational relationships during the 1980's and 1990's? It is argued that decentralisation and the gradual introduction of 
market elements (see figure 6) triggered organisational restructuring as well as adjustments, and that organisational changes have been strongly embedded in the changes of whole social and economic mechanism in Hungary.

The two important and interrelated factors for the transformations in Hungary are the gradual integration of the Hungarian economy into the system of international business (such as international company cooperations and the creation of various forms of strategic alliances) and the privatisation process which simultaneously modernised Hungarian companies in many different dimensions (simultaneously).

The formation of strategic alliances in Hungary has also two main influencing factors (see figure 7). The spread of new forms of cooperation can be linked to the changing global company environment and thus Hungarian companies increasingly start to follow international trends in strategy. Second, one has to consider the past history of Hungarian companies. The companies' search for new solutions to increase competitiveness (such as outsourcing, joint ventures or strategic alliance formation) can be regarded as a movement of reaction against the forced centralisation and against the interference with strategic decisionmaking and against the obstruction of building inter-organisational relationships during the past system.

Figure 7. The context of strategic alliance formation in Hungary (Buzády 2000)

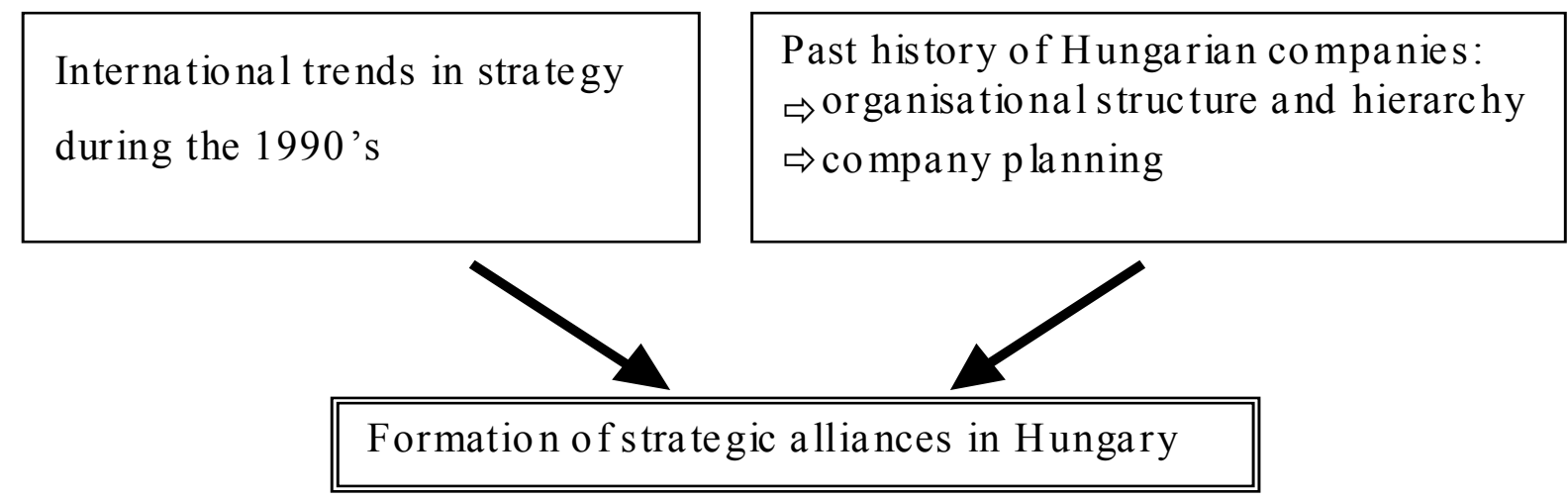

Although the number of strategic alliances has dramatically increased in Hungary, too (see figure 8), little work has been done on exploring the nature of these alliances. At the same time the existing (western) models and theories did not fully represent the observed realities and characteristics of these new cooperations. In the following section a new model, based on empirical studies, will be presented giving a new approach to classify business cooperations in post-transition Hungary. 
Figure 8. Year of strategic alliance formation (sample taken in 1996 summer)

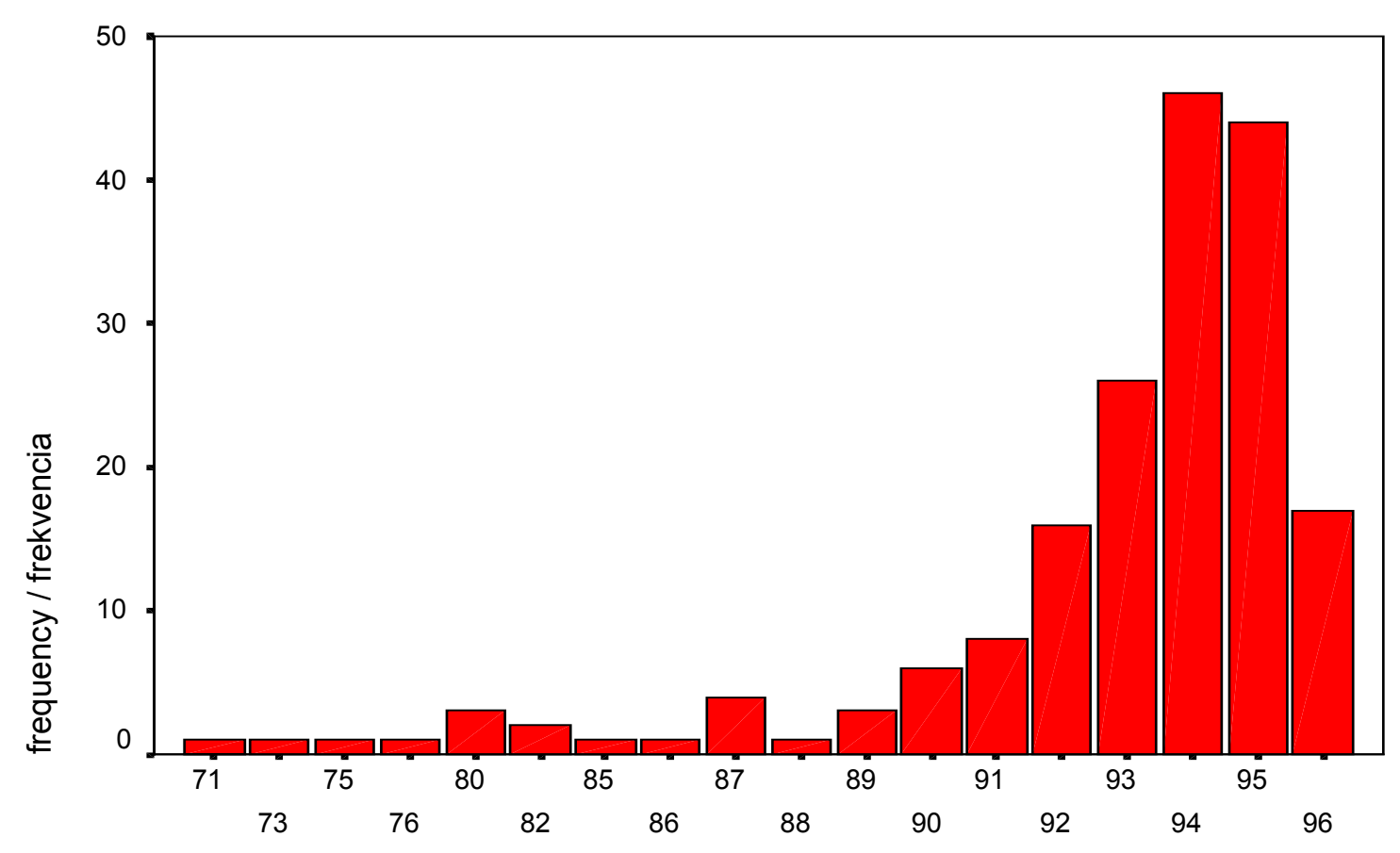

\section{Research Methodology}

Because no systematic analysis data of strategic alliances in Hungary has been conducted to date, the aim of the empirical research was to explore patterns of cooperation and to give new insight into this topic by applying multivariate statistical methods. First to explore new dimensions which simplify the description of the data sample by reducing the number of variables into new factors. Second, to explore possible clusters of Hungarian strategic alliances, which will subsequently be reused to validate the results of the factor analysis.

Despite the fact that the organisation is the dominant level of analysis in alliance research (Oliver/Ebers 1998), the unit of analysis in the present study was the individual strategic alliance of a respondent company.

The strategic alliance questionnaire (see appendix) formed an integral part of the wider questionnaire on Hungarian competitiveness. The respondents were the leading general managers or managers in charge of strategy of the company, i.e. financial, technical or marketing managers were not asked. 13 questions were asked in relation to various aspects of the strategic alliances; each question allowed one respondent company a maximum of three different strategic alliances simultaneously. The characteristics of maximum three different strategic alliances of one respondent company were treated separately. All questions were taken from published research in the field of strategic alliances in order to ensure reliability of scales. 
Concerning the collection of empirical data and its processing the following remarks are necessary. In March 1996 the companies were asked by letter to take part in the survey. A follow-up call by our 78 interviewers resulted in positive answers from 325 companies. Our interviewers visited the companies during a period of two months. Data collection was completed by the end of the third month. The data was entered into a computer database by TARKI (Research Institute for Social Sciences) who edited the basic statistics, too. Subsequently, the data was analysed (factor analysis, cluster analysis) by the author using SPSS.

\section{Research Findings}

\subsection{The sample}

The companies in the sample were chosen from the computer database of the Ministry of Finance. Five thousand six hundred and eighteen companies met the initial requirements. $10 \%$ of these companies received the questionnaire and 325 returned it. According to the data of the Central Statistical Office, the selected companies in 1994 represented $0.6 \%$ of Hungarian enterprises, produced $18 \%$ of GDP and $46 \%$ of exports and employed $18 \%$ of the active population.

In the sample of 325 companies approximately 102 respondents answered the questions related to strategic alliances. The respondents had the possibility to give simultaneously detailed information up to three different strategic alliances at their companies. This gives a total of 196 strategic alliances as a basis for our analysis.

\subsection{Descriptive Statistics}

Concerning the potential influence of the companies' ownership on strategic alliances the following findings were made (table 1). Most crosstabulations between ownership variable and other variables did not produce highly reliable significance levels and thus significantly reduced the importance of the ownership criteria in the context of post-transition alliances and joint ventures. The following table shows that almost $90 \%$ of the alliances were still in process at the time of the survey. However, a tendency towards a more, administrative mode" of dealing with the dynamics of strategic alliances formed by the stateowned companies can be detected. $8 \%$ of alliances by companies in state ownership have been terminated ,according to plan“ or ,prolonged“. In contrast to these, alliances by companies in domestic and foreign private ownership show more market dynamics in the way alliances develop. 8 to $12 \%$ of the alliances have been renegotiated, prematurely terminated or bought out by one of the partners. 
Table 1. Crosstabulation Ownership and outcome of alliance (sign.. .18)

\begin{tabular}{|l|l|l|l|l|}
\hline $\begin{array}{l}\text { Outcome of the } \\
\text { alliance: }\end{array}$ & $\begin{array}{l}\text { State-owned } \\
\text { company }\end{array}$ & $\begin{array}{l}\text { Hungarian } \\
\text { privately-owned } \\
\text { company }\end{array}$ & $\begin{array}{l}\text { Foreign-owned } \\
\text { company }\end{array}$ & Total \\
\hline Still in progress & $89.8 \%$ & $87.5 \%$ & $91.7 \%$ & $89.9 \%$ \\
\hline $\begin{array}{l}\text { Terminated } \\
\text { according to } \\
\text { plan }\end{array}$ & $4.1 \%$ & $?$ & $?$ & $2.5 \%$ \\
\hline Prolonged & $4.1 \%$ & $?$ & $5.6 \%$ & $3.8 \%$ \\
\hline $\begin{array}{l}\text { Premature } \\
\text { termination }\end{array}$ & & $4.2 \%$ & $2.8 \%$ & $1.3 \%$ \\
\hline $\begin{array}{l}\text { Partner bought } \\
\text { out }\end{array}$ & $2 \%$ & $8.3 \%$ & $?$ & $2.5 \%$ \\
\hline Total & $100 \%$ & $100 \%$ & $100 \%$ & $100 \%$ \\
\hline
\end{tabular}

An interesting although not significantly reliable picture emerges from the following table (table 2). Foreign-owned companies do not seem to differentiate between domestic and foreign-owned alliance partners. In contrast, Hungarian companies (much more) prefer fellow Hungarian alliance partners. The companies in state ownership have the highest proportion of mixed alliance partners.

Table 2. Crosstabulation Ownership and Ownership of Alliance Partner (sign.: .38)

\begin{tabular}{|l|l|l|l|l|}
\hline $\begin{array}{l}\text { Alliance } \\
\text { partner }\end{array}$ & $\begin{array}{l}\text { State-owned } \\
\text { company }\end{array}$ & $\begin{array}{l}\text { Hungarian } \\
\text { privately-owned } \\
\text { company }\end{array}$ & $\begin{array}{l}\text { Foreign-owned } \\
\text { company }\end{array}$ & Total \\
\hline Domestic & $56.3 \%$ & $70.8 \%$ & $48.6 \%$ & $56.8 \%$ \\
\hline Foreign & $38.5 \%$ & $29.2 \%$ & $48.6 \%$ & $39.4 \%$ \\
\hline Both & $5.2 \%$ & $?$ & $2.9 \%$ & $3.9 \%$ \\
\hline Total & $100 \%$ & $100 \%$ & $100 \%$ & $100 \%$ \\
\hline
\end{tabular}

Significant predictions can be made concerning the strategic position of the companies at the start of the cooperation process (table 3): Foreign companies only enter alliances from dominant or at least equal strategic positions. Hungarian privately-owned companies show the strongest tendency to be either in strong or in weak strategic position, whilst alliances of state-owned companies are mostly made from balanced, equal strategic positions. It should be noted, however, that the judgement of the company's strategic position was made by the questioned company CEOs themselves.

With sufficient level of significance we can observe (see table 4.) that stateowned companies are more likely to enter alliance with identical inputs by the partners, that is quasi-concentration horizontal alliances. Hungarian privately owned companies tend to make complementary horizontal alliances or vertical cooperations. 
Table 3. Crosstabulation Ownership and Strategic Position at entering into alliance (sign.: .01)

\begin{tabular}{|l|l|l|l|l|}
\hline $\begin{array}{l}\text { Strategic } \\
\text { Position at start } \\
\text { of Alliance }\end{array}$ & $\begin{array}{l}\text { State-owned } \\
\text { company }\end{array}$ & $\begin{array}{l}\text { Hungarian } \\
\text { privately-owned } \\
\text { company }\end{array}$ & $\begin{array}{l}\text { Foreign-owned } \\
\text { company }\end{array}$ & Total \\
\hline Dominant & $20.4 \%$ & $30.4 \%$ & $22.2 \%$ & $22.3 \%$ \\
\hline Equal & $56.1 \%$ & $43.5 \%$ & $77.8 \%$ & $59.2 \%$ \\
\hline Subordinate & $23.5 \%$ & $26.1 \%$ & & $18.5 \%$ \\
\hline Total & $100 \%$ & $100 \%$ & $100 \%$ & $100 \%$ \\
\hline
\end{tabular}

Table 4. Crosstabulation Ownership and Nature of inputs into the alliance(sign.: .05)

\begin{tabular}{|l|l|l|l|l|}
\hline $\begin{array}{l}\text { Nature of } \\
\text { inputs } \\
\text { alliance }\end{array}$ & $\begin{array}{l}\text { State-owned } \\
\text { company }\end{array}$ & $\begin{array}{l}\text { Hungarian } \\
\text { privately-owned } \\
\text { company }\end{array}$ & $\begin{array}{l}\text { Foreign-owned } \\
\text { company }\end{array}$ & Total \\
\hline Identical & $61.2 \%$ & $34.8 \%$ & $50 \%$ & $54.8 \%$ \\
\hline Different & $38.8 \%$ & $65.2 \%$ & $50 \%$ & $45.2 \%$ \\
\hline Total & $100 \%$ & $100 \%$ & $100 \%$ & $100 \%$ \\
\hline
\end{tabular}

\subsection{Factor analysis and cluster analysis results}

The Principal Component Analysis was used to find factors which help to describe the observed variables along fewer dimensions. Although five factors were computed with Eigenvalues over 1.0, based on the Scree plot curve (see figure 9.), four factors retained for the analysis.

Figure 9. Eigenvalues and total variance explained

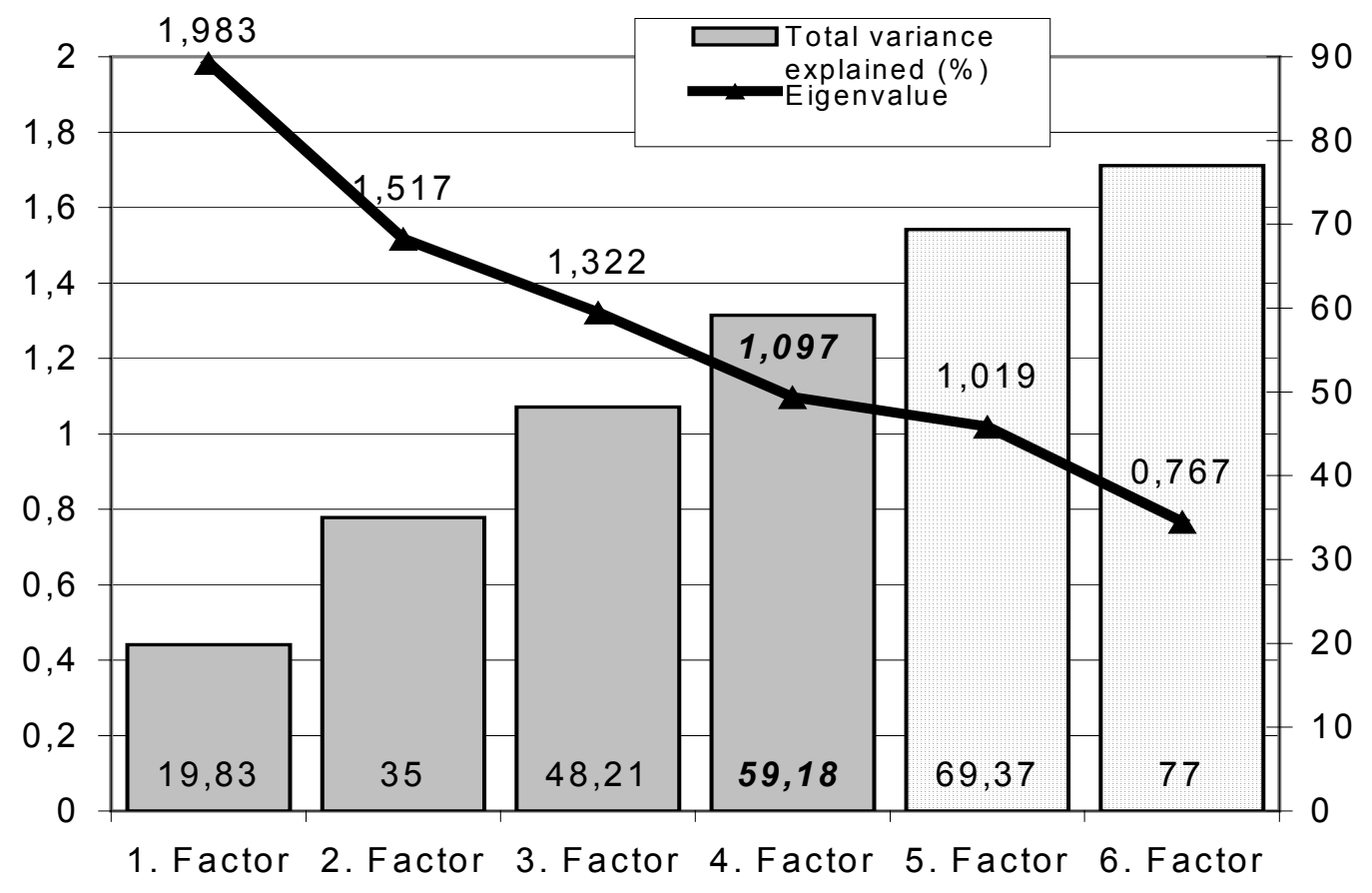


The four factors (see table 5.) used cumulatively explain almost $60 \%{ }^{2}$ of total variance and are therefore useful for further statistical operations.

Based on the rotated component matrix the factors can be described as follows:

Factor 1 can be explained as being

- negatively related to non-equity alliances, i.e. strongly linked to equity alliances,

- in connection with alliances formed for a not predetermined time period and

- linked to multi-party alliances.

Factor 2 can be explained as being

- linked to alliances formed from subordinate strategic positions and

- linked to the presence of both foreign and domestic alliance partners.

Table 5. Rotated Component Matrix

\begin{tabular}{|c|c|c|c|c|c|}
\hline & \multicolumn{5}{|c|}{ Component } \\
\hline & 1 & 2 & 3 & 4 & 5 \\
\hline V16 & .107 & $5.1 \mathrm{E}-02$ & .640 & -.422 & -.399 \\
\hline V18A & .659 & .246 & $-3.63 \mathrm{E}-02$ & -.417 & .186 \\
\hline V20A & .571 & -.471 & -.149 & $4.933 \mathrm{E}-03$ & -.231 \\
\hline V21A & $9.946 \mathrm{E}-02$ & .739 & .146 & .136 & -.184 \\
\hline V22TYPE & -.354 & .194 & .468 & .419 & -.339 \\
\hline V23CLASF & .119 & $5.4 \mathrm{E}-02$ & -.840 & -.113 & $-8.14 \mathrm{E}-02$ \\
\hline V24 & -.750 & 9.2E-02 & $4.070 \mathrm{E}-02$ & -.265 & $-5.26 \mathrm{E}-02$ \\
\hline V25A & -.153 & .748 & -.171 & -.131 & 5.733E-02 \\
\hline V26A & 7.554E-02 & -7.E-02 & $1.047 \mathrm{E}-02$ & $-6.70 \mathrm{E}-03$ & .897 \\
\hline V27A & .115 & $1.1 \mathrm{E}-02$ & $2.388 \mathrm{E}-02$ & .834 & $-3.04 \mathrm{E}-03$ \\
\hline
\end{tabular}

Extraction Method: Principal Component Analysis

Rotation Method: Varimax with Kaiser Normalization, a rotation converged in 12 iterations

Factor 3 can be explained as being

- negatively related to alliances with more than two functional areas, i.e. single functional and

- linked to cases where the company has formed more than one alliance simultaneously.

- (Factor 3 is also to some extend linked to buyer/supplier alliances).

2 Antal and Kovacs published a study on the content of corporate strategy in Hungary. They based their analysis on the same large overall questionnnaire. In their factor analysis nine factors were needed to explain $62.9 \%$ of variance (Antal-Mokos and Kovács 1998). 
Factor 4 has only high factor loading scores (.83) on a single variable V27 (Strategic Impact of Alliance).

Factor 5 has only high factor loading scores (.90) on a single variable V26 (Nature of Inputs into Alliance).

Because Factors 4 and Factors 5 do not contain more information than the single variables alone they cannot further be treated as ,composite factors“.

The cluster analysis produced three cluster groups. The following table (table 6.) and figure (figure 10.) shows the equal distribution of the alliances into the three clusters.

Table 6. Clustergroup sizes

\begin{tabular}{|c|c|c|c|c|c|}
\hline \multicolumn{2}{|c|}{} & Frequency & Percent & Valid Percent & $\begin{array}{c}\text { Cumulative } \\
\text { Percent }\end{array}$ \\
\hline Valid & 1 & 53 & 27.0 & 37.1 & 37.1 \\
\cline { 3 - 6 } $\begin{array}{c}\text { Cluster } \\
\text { s }\end{array}$ & 2 & 59 & 30.1 & 41.3 & 78.3 \\
\cline { 3 - 6 } & 3 & 31 & 15.8 & $21.7 \mathrm{a}$ & 100.0 \\
\cline { 3 - 6 } & Total & 143 & 73.0 & 100.0 & \\
\cline { 3 - 6 } $\begin{array}{c}\text { Missing } \\
\text { Total }\end{array}$ & & 53 & 27.0 & & \\
\cline { 3 - 6 } & & 196 & 100.0 & & \\
\cline { 3 - 6 } & & & & \\
\hline
\end{tabular}

Figure 10. Cluster group sizes (2)

Cluster Groups Sizes

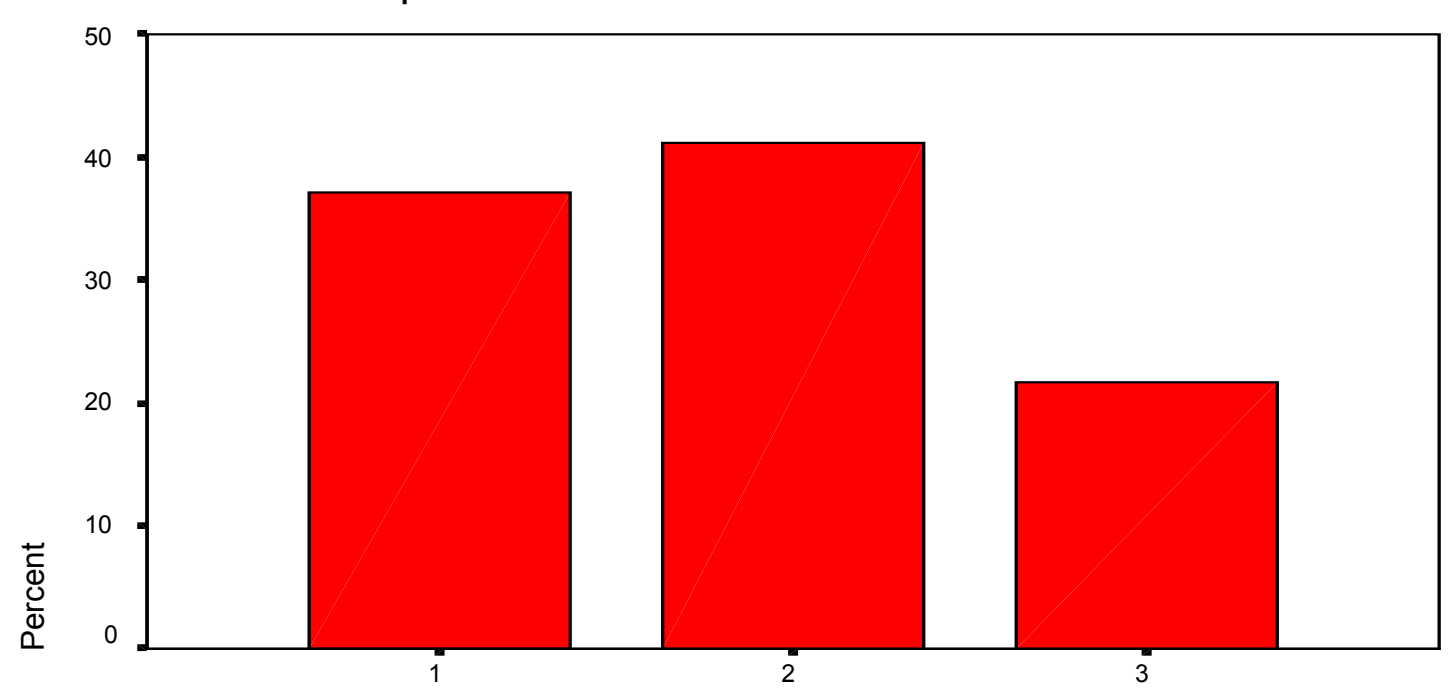

Ward Method

The Analysis of Variance (ANOVA) was used to test the homogeneity of the cluster groups. The following table (table 7.) shows that all three clusters have 
standard deviations of less than 1.000 on Factors 1 and 2. Cluster 1 is also homogenous on Factor 3.

Table 7. Cluster homogeneity and cluster means

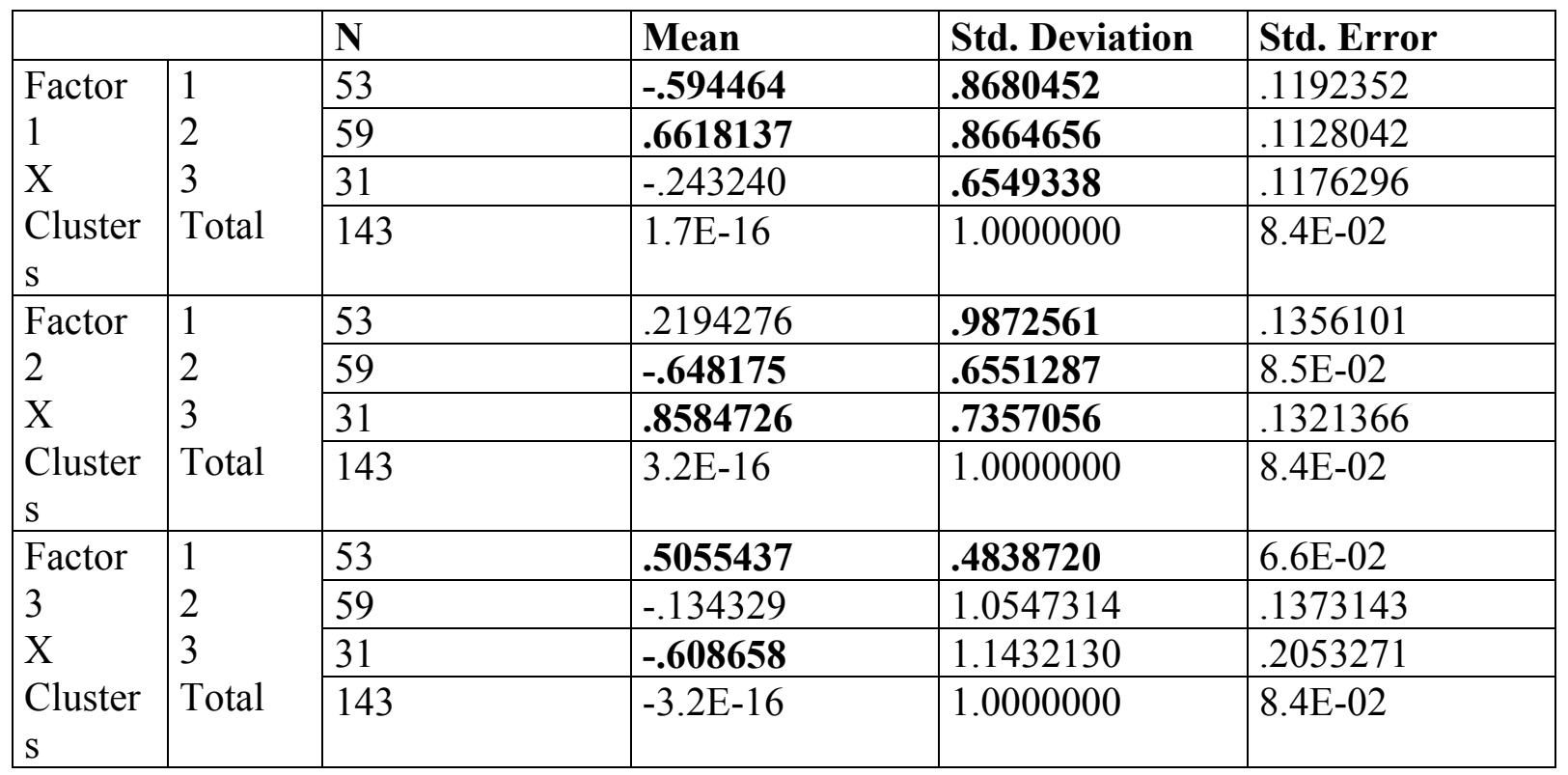

The means shown in the same table were used to interpret the three clusters:

- Factor 1 is most characteristic for Clusters 1 and 2, although in opposite direction (-.59 and .66).

- Factor 2 distinguishes best between Clusters 2 and 3 (-.65 and .86).

- Factor 3 draws the line between Clusters 1 and 3 (.51 and -.61). 
Figure 11. Scatterplot: Cluster groups on factor 1 and factor 2

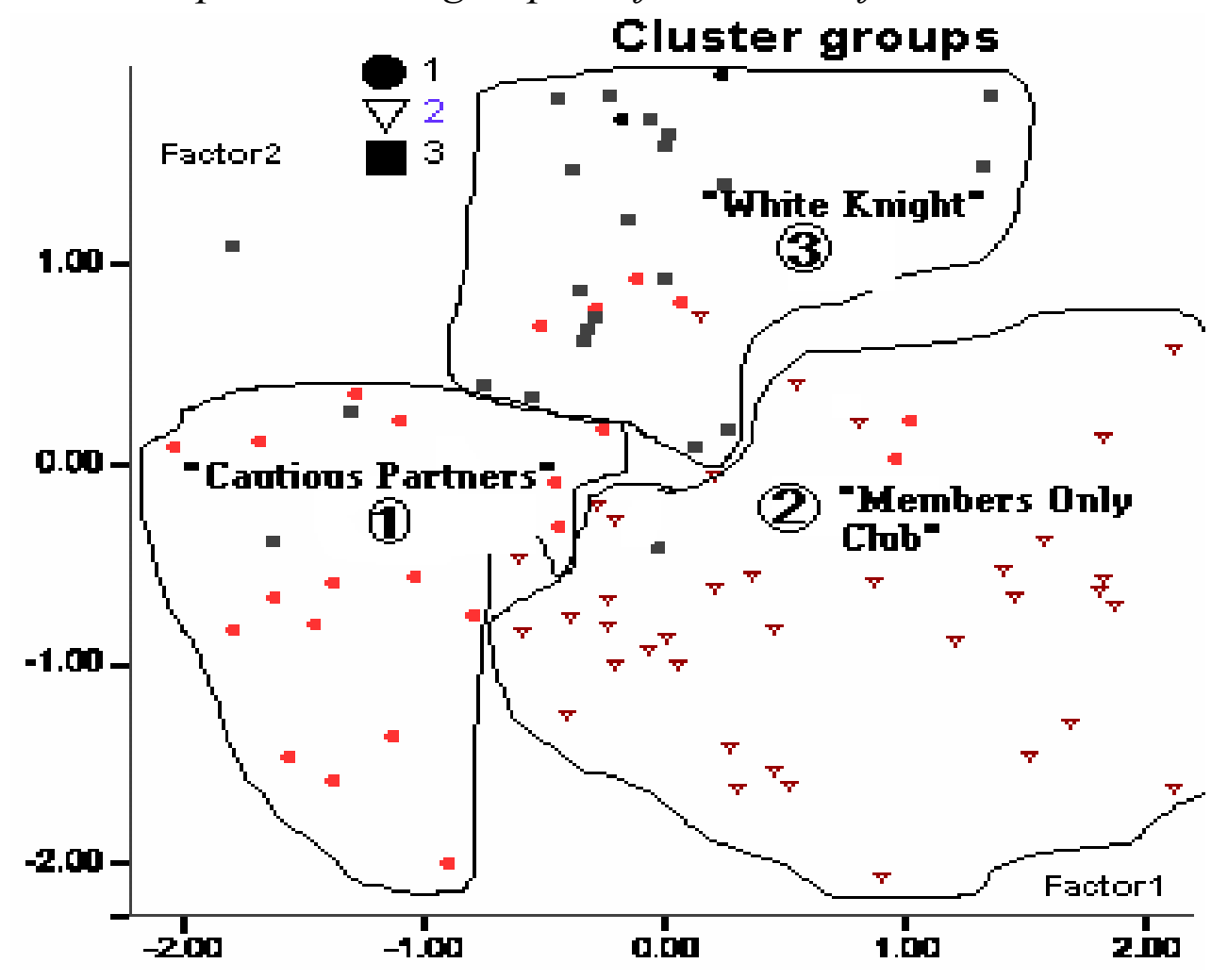

The visible output (see figure 11.) also show the existence of the three distinct groups of strategic alliances, which can be described along the three Factors.

Cluster 1 alliances are:

- Informal or contractual alliances (i.e. non-equity) for a determined time period and bilateral,

- Single functional alliances, but the company has formed more than one alliance simultaneously. In tendency these are buyer/suppliers of vertical alliances.

Cluster 2 alliances are:

- Equity alliances, for a not predetermined time period and are multi-party,

- Formed by companies in superior strategic positions, mostly with either a domestic or foreign partner.

Cluster 3 alliances are:

- Formed by companies in subordinate strategic positions with both domestic and a foreign partners;

- In tendency, unfocused concerning number of functions; the company has formed not more than one alliance at a time. 


\section{Groups of Strategic Alliances:}

The factor analysis has presented three underlying factors with the help of which the sampled strategic alliances can be represented (48\% of variance) along fewer dimensions than the initial independent variables.

The cluster analysis has presented three clusters into which strategic alliances in post-transition Hungary can be regrouped:

\section{The „Cautious Partners”}

Cluster 1 represents those alliances which can be described with the motto „better safe than sorry“ or „do not keep all your eggs in one basket“. These companies are mostly in vertical buyer-supplier relationships. Their increasingly integrated activities induce them to establish strategic cooperations in form of informal or simple contractual agreements for a predetermined time period. These alliances are between two partners and for one precise function. However, these companies perceive a risk in being fully dependent on the alliance partner. They therefore form several cooperation agreements with other vertically linked companies simultaneously at a time. Characteristic for this group is that the market forces them to integrate with each other through alliances but the companies try to retain some of their independence and, therefore, chose informal or simple contractual arrangements, which are easy to exit.

\section{The „Members Only Club”}

Cluster 2 represents the group of alliances which are rather closed. These alliances are highly formal and structured, in form of equity agreements i.e. joint ventures. The alliance is formed amongst a few partners, but being a joint venture also infers that the membership changes (old and new) are almost excluded. These companies are in superior strategic positions, they are clear about their interests and about the goals of the cooperation. The club members have made up their mind whether to join a club of domestic or of foreign alliance partners. For this group it is characteristic that the companies themselves initiate the process of closer integration and they have chosen to be closed for other potential partners.

\section{„Waiting for the White Knight"}

Cluster 3 represents the smaller group of companies waiting for help by any possible partner willing to co-operate. These companies are in weak and subordinate strategic positions. Their alliances are less focused and cover more than two functional areas. Characteristic for this group is that the companies are forced to co-operate due to their weak strategic position, i.e. forced to be open for potential partners. However, once they have entered an alliance these companies do not enter new cooperations. They have only one alliance at a time. It is assumed that either the other partner in the stronger strategic position forces 
these companies to exclusivity, or they do not have any spare capacity for managing a second alliance.

Table 8. Crosstabulation Cluster groups and Strategic Impact of Alliance

\begin{tabular}{|l|l|l|l|l|}
\hline $\begin{array}{l}\text { Impact of strategic } \\
\text { alliance }\end{array}$ & $\begin{array}{l}\text { Cluster 1 } \\
\text { „cautious } \\
\text { partners" }\end{array}$ & $\begin{array}{l}\text { Cluster 2 } \\
\text { „members only } \\
\text { club” }\end{array}$ & $\begin{array}{l}\text { Cluster 3 } \\
\text { „waiting for the } \\
\text { white knight” }\end{array}$ & Total \\
\hline No strategic change & & $11.9 \%$ & $29 \%$ & $11.2 \%$ \\
\hline Favourable change & $100 \%$ & $86.4 \%$ & $61.3 \%$ & $86 \%$ \\
\hline $\begin{array}{l}\text { Unfavourable } \\
\text { change }\end{array}$ & $1.7 \%$ & $9.7 \%$ & $2.8 \%$ \\
\hline Total & $100 \%$ & $100 \%$ & $100 \%$ & $100 \%$ \\
\hline
\end{tabular}

The table above (table 8.) demonstrates the described tendencies. All alliances in the „cautious partners" cluster group have had positive effects on the strategic position of companies. Alliances by the so-called „members only club" have had positive or no influence on the strategic position of parent companies. Interestingly, the alliances in the third cluster group, ,waiting for the white knight", have experienced the most disappointing effects of cooperation. Not only that these companies are in weaker strategic positions at the start of the alliance but also less than $2 / 3$ of them actually experienced a favourable change to their strategic position. Almost one in ten companies in this particular cluster group judged the alliance entered to have been an unfavourable one!

\section{General conclusions:}

Strategic alliances might be seen as a „management fashion“. In contrast to this statement, the present empirical quantitative research has not only shown the growing number of strategic alliances in Hungary, but has also proven that managers judge alliance to have a positive impact on the strategic position of companies. Strategic alliances are a vital element of and an important tool for the corporate strategies of Hungarian companies.

The most important result is that not all alliances follow the same reasoning and raison d'être. Different strategic approaches to alliances bring different results to cooperation and to partners.

The literature overview presented an extensive range of models, all aimed at demonstrating possible groupings of different strategic alliances. The present empirical research of Hungarian strategic alliances has revealed a new tripartite alliance typology (White Knights, Members Only Clubs and Cautious Partners), which much better describes the nature of strategic alliances in the posttransition market economy of Hungary. 
The author intends to conduct follow -up studies on the evolution of the proposed three alliance groups and to engage in international, comparative research projects on alliances in the CEE region.

\section{References}

Adorján, M./Balaton, K.(1996): Gazdasági szervezetek az átalakulás idöszakában; szereplök és stratégiák (tulajdonosi és szervezeti átalakulás vállalati példája) (Business organisations in the transition period - actors and strategies), Budapest University of Economic Sciences, Hungary.

Zoltán, A.-M./Kovács, P. (1998): Magyar vállalati stratégiák az 1990-es évek első felében taxonomia (Taxonomy of company strategies in Hungary 1990-1995): Vezetéstudomány (Management Science) 29(2), 23-34.

Arndt, J. (1979): Toward a Concept of Domesticated Markets. Journal of Marketing, 43, 6975.

Bidault, F. (1996): Alliances can bring you hidden benefit, IMD, Lausanne.

Bidault, F./Cummings, T. (1994): Innovating through alliances: expectations and limitations. R\&D Management 24(1): 33-45.

Bruszt, L.,Stark, D. (1998): Restructuring Networks. Postsocialist Pathways - Transforming Politics and Property in East Central Europe. László Bruszt and David Stark. UK, Cambridge University Press.

Buzády, Z. (2000): Strategic Alliances in Hungary., Ph.D. thesis, Faculty of Business Administration, Budapest University of Economic Sciences and Public Administration

Buzády, Z./Tari, E. (2002): Vállalati versenyképesség a globalizálódó magyar gazdaságban.(Corporate competitiveness in a globilising Hungarian economy), Chikán A./ Czakó E./Zoltayné Paprika, Z. (eds.), 137-157.

Bühner, R. (1993): Diversifikation durch strategische Allianzen. In: Strategie und Organisation: Analyse und Planung der Unternehmens diversification mit Fallbeispielen. Wiesbaden, Der Gabler Verlag.

Child, J./Markóczy, L. (1993): Host-country managerial behaviour and learning in Chinese and Hungarian joint ventures. Journal of Management Studies 30(4): 611-631.

Dussauge, P./Garrette, B. (1993): Chemical Labour. Stratégie d'Entreprise: Études de Cas. P. Dussauge and B. Garrette. Paris, InterEdition.

Dussauge, P./Garrette, B. (1995): Determinants of Success in International Strategic Alliances: Evidence from the Global Aerospace Industry. JIBS 26(3), 505-530.

Faulkner, D. (1995): International Strategic Alliances: Co-operating to Compete. Maidenhead, England, McGraw-Hill.

García-Canal, D. (1996): Contractual form in domestic and international strategic alliances." Organization Studies 17(No. 5), 773-794.

Ghemavat, J.M./Porter, M./Rawlinson, R.A. (1986): Patterns of International Joint Ventures. Competition in Global Industries. M.E. Porter. Boston, MA, Harvard Business School Press, 345-366. 
Hamel, G./Doz, Y./Prahalad, C. (1989): Collaborate with your competitors and win. HBR 67(Jan/Feb), 133-139.

Hennart, J-F. (1988): A transaction costs theory of equity joint ventures. SMJ 9(361-374).

Hergert, M./Morris, D. (1987): Trends in International Collaborative Agreements. CJWB 22, $15-21$.

Lorange, P./Roos, J. (1992): Strategic Alliances: Formulation, Implementation, and Evolution. Oxford, UK, Blackwell.

Oliver, A./Ebers, M. (1998): Networking Network Studies: An Analysis of Conceptual Configurations in the Study of Inter-Organisational Relationships. Organisation Studies 19(4), 549-583.

Pisano, G.P. (1989): Using equity participation to support exhange: Evidence form the biotechnology industry. Journal of Law, Economics and Organisation 5(1), 109-126.

Porter, M. (1985): The Value Chain and Competitive Advantage, in: Competitive Advantage. New York, The Free Press, 33-61.

Tari, E. (1988): Iparvállalatok belső irányítási szervezete (Internal management structure of industrial companies). Budapest, KJK.

Tari, E./Buzády, Z. (1998): Stratégiai szövetségek a piacgazdasági átmenet lezárulásának időpontjában (Strategic alliances at the end of the Hungarian transformation process). Vezetéstudomány 29(2), 35-47.

Yoshino, M./Rangan, S. (1995): Strategic Alliances: an entrepreneurial approach to globalisation. Boston, MA, Harvard Business School Press.

\section{Appendix - Questionnaire section on strategic alliances}

V15. Has your company created a longer termed co-operation (strategic alliance) with another organisation or company, whilst maintaining your strategic independence and by integrating your activities to a certain degree, for the purpose of securing or enhancing your competitiveness.

IF not, please continue with question V28!

V16. How many alliances is your company engaged in? one several

In the case of several alliances, please consider the three most important ones as separate alliances $\mathrm{A}, \mathrm{B}$ and $\mathrm{C}$.

V17. When did you start the strategic alliance? Year

A

$\mathrm{B}$

$\mathrm{C}$

V18. For which time period was the strategic alliance designed envisaged?
A $\quad \square$ for ... years
$\square$ for an undefined time span
B $\square$ for ... years
$\square$ for an undefined time span
C $\square$ for ... years
$\square$ for an undefined time span 
V19. Which status is the alliance currently in: A
a) still continuing
b) terminated according to plans
c) prolonged or renewed
d) premature termination
e) one alliance partner acquired the other partner

V20. How many partners are in the alliance?

Two Several partners
A
B
C

V21. Who are the alliance partners?

Foreign Domestic

partners
A
$\mathrm{B}$
C

V22. The partners are

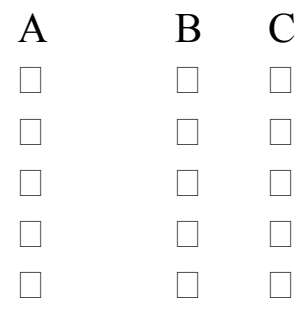

V23. What is the scope of the strategic alliance?

A $\quad$ B C
a) $\mathrm{RnD}$
b) Production
c) Marketing and Sales
d) Sourcing and Logistics
e) Several functions simultaneously
f) other, please specify.

V24. What is the legal form of the strategic alliance?

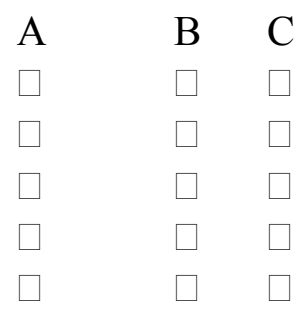
a) informal agreement
b) formal, written agreement
c) separate legal entity ( JV, consortium etc.)
d) minority cross-shareholding
e) other, please specify.

V25. Your company's strategic positioning at the beginning of the alliance:
a) dominant position
b) equal position
c) subordinate position 
V26. The nature of the assets/know-how contributed to the alliance by the partners is:
a) similar
b) different

V27. The effect of the strategic alliance on your company's competitiveness:
a) no influence
b) positive influence
c) negative influence 